\title{
SISTEM PREDIKSI PENGGUNAAN LISTRIK PELANGGAN DI PT.PLN (PERSERO) RAYON LAMONGAN AREA BOJONEGORO DENGAN METODE TRIPLE EXPONENTIAL SMOOTHING (BROWN)
}

\author{
(Prediction System Of Customer Electricity Use In PT. Pln (Persero) Rayon Lamongan Area \\ Bojonegoro Using Triple Exponential Methods Smoothing (Brown)) \\ Maslucha \\ Prodi. Teknik Informatika, Fakultas Teknik, Universitas Muhammadiyah Lamongan \\ Jl. Raya Plalangan, Plosowahyu, Lamongan, Lamongan 62218 \\ Email: mbakmaslucha@gmail.com
}

\begin{abstract}
Electricity is one of the means of fulfilling the needs of human life which is very important in this era. Excessive use of electricity will have an impact on the high use of electricity $\mathrm{kWh}$. The process of recording $\mathrm{kWh}$ on the customer meter is carried out by officers from PLN who routinely visit the customer's homes once a month. The meter recording clerk cannot record when the customer's house cannot be reached resulting in empty customer $\mathrm{kWh}$ data. Prediction System Using Electricity Customers at PT. PLN Lamongan aims to determine the amount of electricity usage $\mathrm{kWh}$ of the customer for the next period. This research uses the Triple Exponential Smoothing method (Brown). The calculation is done on 10 different customers with $\mathbf{2 4}$ data, namely the use of electric $\mathrm{kWh}$ per period from January 2015 to December 2016 with 9 different alpha values, namely alpha $0.1-0.9$ and uses a reference of 3 months, 6 months and 12 months before. Prediction results will be compared with the actual data of $\mathrm{kWh}$ to determine the failure value or error value in predictions using mean absolute deviaton (MAD) and mean absolute percentage error (MAPE). From the third average forecasting test analysis, it produces an average MAPE value of 3 months reference with an average value of $2.922 \%, 6$ months reference with an average value of $3.092 \%$ and a 12-month reference with an average value of $4.175 \%$. The smallest MAPE, which is a test using a 6-month reference, produces a value of $1.886 \%$ with alpha 0.1 .
\end{abstract}

Key word : Triple Exponential Smoothing (Brown), Mean Absolute Deviation, Mean Absolut percentage Error.

\section{PENDAhUluan}

PT. PLN (Persero) Rayon Lamongan Area Bojonegoro merupakan salah satu PT. PLN Distribusi Jawa Timur yang bertugas menyediakan tenaga listrik di area Lamongan meliputi pembangkitan (generator), transmisi, distribusi dan penjualan tenaga listrik kepada konsumen. Listrik merupakan salah satu alat pemenuhan kebutuhan hidup manusia yang sangat penting pada era ini karena hampir sebagian besar mesin-mesin yang digunakan oleh manusia dalam kehidupan sehari-hari menggunakan energi listrik. Penggunaan energi listrik di rumah tangga dalam kehidupan sehari-hari untuk peralatan elektronik alat rumah tangga. Penggunaan listrik yang berlebihan tentu akan berdampak pada tingginya penggunaan $\mathrm{kWh}$ listrik. Hal tersebut dapat merugikan pengguna itu sendiri karena tingginya penggunaan $\mathrm{kWh}$ listrik dapat mengakibatkan tagihan beban biaya listrik semakin besar pula.

Proses pencatatan $\mathrm{kWh}$ pada meteran pelanggan dilakukan oleh petugas dari PLN secara rutin mendatangi rumah-rumah pelanggan setiap akhir bulan sekali dalam sebulan. Permasalahan yang dialami oleh petugas pada saat melakukan pencatatan meteran ditemui beberapa kendala, seperti rumah pelanggan yang kosong dan pagar terkunci. Akibatnya petugas tidak dapat mengetahui penggunaan $\mathrm{kWh}$ listrik pelanggan pada bulan tersebut. Untuk mengatasi masalah itu petugas pencatat meteran mengambil hasil penggunaan rata-rata dari penggunaan listrik beberapa bulan sebelumnya untuk tagihan bulan berikutnya. Solusi pengambilan rata-rata dalam mengetahui penggunaan $\mathrm{kWh}$ listrik pelanggan dirasa kurang tepat karena jika salah dalam menentukan tagihan dapat menimbulkan kerugian bagi pihak PLN atau pelanggan PLN.

Diperlukan suatu alat yang dapat membantu memutuskan dalam menentukan penggunaan $\mathrm{kWh}$ listrik pelanggan kedepannya berdasarkan data pengguna $\mathrm{kWh}$ listrik pelanggan beberapa bulan sebelumnya. Sistem prediksi yang akan dikembangkan dalam penelitihan ini, menggunakan metode Triple Exponential Smoothing (Brown). Metode ini sebagaimana halnya dengan pemulusan eksponensial liniear yang dapat digunakan untuk meramalkan data dengan suatu pola trend dasar, bentuk pemulusan yang lebih tinggi ini dapat digunakan bila dasar pola datanya adalah kuadratik, kubik, atau orde yang lebih tinggi. Maka dari itu, penulis melakukan penelitihan yang berjudul "Sistem Prediksi Penggunaan Listrik Pelanggan di PT PLN (Persero) Rayon Lamongan 
Area Bojonegoro dengan Metode Triple Exponential Smoothing (Brown)".

Sistem prediksi penggunaan $\mathrm{kWh}$ listrik pelanggan diharapkan dapat membantu petugas pencatat meteran dalam menentukan penggunaan $\mathrm{kWh}$ listrik pelanggan yang ksosong. Selain untuk petugas pencatat meteran, sistem yang akan dibuat juga diharapkan dapat membantu pelanggan PLN Lamongan untuk mengetahui penggunaan kWh listrik rumahnya pada periode selanjutnya. Sehingga dengan hasil prediksi penggunaan $\mathrm{kWh}$ listrik pelanggan dapat mengatur penggunaan listrik rumahnya dengan bijak.

\section{II.TINJAUAN PUSTAKA}

\section{A. Pengertian Peramalan (Forecasting)}

Peramalan (forecasting) diperlukan untuk menetapkan patokan dalam membuat rencana. Tanpa adanya patokan (dasar), tidak mungkin rencana bisa dibuat. Ramalan penjualan diperlukan untuk menentukan jumlah produksi baik jasa maupun barang yang harus dipersiapkan. Peramalan dapat dilakukan secara kuantitatif dan kualitatif. Pengukuran secara kuantitatif yaitu dengan mengguanakan metode statistik sedangkan pengukuran secara kualitatif yaitu dengan berdasarkan pendapat. Berdasarkan uraian tersebut peramalan dikenal dengan istilah prakiraan dan prediksi.

Untuk lebih memahami definisi mengenai peramalan, penulis mengemukakan beberapa pendapat para ahli, yaitu: Pengertian prediksi menurut Eddy Herjanto (2008 : 78) mendefinisikan : "prediksi adalah proses peramalan di masa datang dengan lebih mendasarkan pada pertimbangan intuisi, dalam prediksi juga sering digunakan data kuantitatif sebagai pelengkap informasi dalam melakukan peramalan". Sedangkan "prakiraan didefinisikan sebagai proses peramalan (kejadian) di masa datang dengan berdasarkan data variabel di masa sebelumnya."

Dari uraian tersebut dapat disimpulkan bahwa terdapat perbedaan antara peramalan dan prediksi. Peramalan dilakukan perusahaan bilamana kondisi perusahaan sudah berjalan sebagaimana mestinya atau proses produksi telah berjalan sehingga terdapat data masa lalu yang dijadikan dasar untuk melakukan prakiraan. Sedangkan prediksi dilakukan bila proses produksi baru akan berjalan, dalam hal ini perusahaan belum mempunyai data masa lalu untuk dijadikan dasar untuk membuat suatu prakiraan. Sedangkan pengertian peramalan menurut Roger G. Scroeder (2003 : 205) mendefinisikan : “Forecasting is the art and science of prodicting future events ". Artinya : "Peramalan adalah seni dan ilmu dalam memprediksi kejadian di masa yang akan datang."

Sejalan dengan itu menurut Jay Heizer dan Barry Rounder yang telah diterjemahkan "Peramalan adalah seni dan ilmu dalam memprediksi kejadian masa yang akan datang dengan menggunakan data masa lalu dalam menentukan kejadian yang akan datang dengan pendekatan matematis." Dari uraian yang telah dipaparkan penulis maka dapat ditarik sebuah kesimpulan bahwa peramalan adalah ilmu atau seni yang digunakan sebuah manajemen dalam memprediksi kejadian di masa yang akan datang dengan menggunakan data masa lalu yang diolah menggunakan metode-metode tertentu.

\section{B. Triple Exponential Smoothing: Metode Kuadratik Satu-Parameter Dari Brown}

Metode ini sebagaimana halnya dengan pemulusan eksponensial liniear yang dapat digunakan untuk meramalkan data dengan suatu pola trend dasar, bentuk pemulusan yang lebih tinggi ini dapat digunakan bila dasar pola datanya adalah kuadratik, kubik, atau orde yang lebih tinggi. Untuk berangkat dari pemulusan kuadratik, pendekatan dasarnya adalah memasukkan tingkat pemulusan tambahan (pemulusan triple) dan memberlakukan persamaan peramalan kuadratik.

Berikut adalah persamaan matematis untuk pemulusan triple exponential smoothing brown:

Pemulusan Tunggal

$$
S_{t}^{\prime}=\alpha \chi_{t}+(1-\alpha) S_{t-1}^{\prime}
$$

Pemulusan Ganda

$$
S_{t}^{\prime \prime}=\alpha S_{t}^{\prime}+(1-\alpha) S_{t-1}^{\prime \prime}
$$

Pemulusan Tripel

$$
S_{t}^{\prime \prime \prime}=\alpha S_{t}^{\prime \prime}+(1-\alpha) S_{t-1}^{\prime \prime \prime}
$$

Pemulusan Total

$$
a_{t}=3 S_{t}^{\prime}-3 S_{t}^{\prime \prime}+S_{t}^{\prime \prime \prime},
$$

Pemulusan Tren

$$
\begin{aligned}
& b_{t}=\frac{\alpha}{2(1-\alpha)^{2}}\left[(6-5 \alpha) S_{t}^{\prime}-(10-8 \alpha) S_{t}^{\prime \prime}+\right. \\
& (4-3 \alpha) S_{t}^{\prime \prime \prime}
\end{aligned}
$$

Pemulusan Kuadratik

$$
C_{t}=\frac{\alpha^{2}}{(1-\alpha)^{2}}\left(S_{t}^{\prime}-2 S_{t}^{\prime \prime}+S_{t}^{\prime \prime \prime}\right)
$$

Peramalan

$$
F_{t+m}=a_{t}+b_{t} m+\frac{1}{2} c_{t} m^{2}
$$

Ket : $\quad \begin{array}{ll}S^{\prime}{ }_{t} & =\text { Nilai pemulusan tunggal } \\ S^{\prime \prime}{ }_{t} & =\text { Nilai pemulusan ganda } \\ S_{t}^{\prime \prime \prime} & =\text { Nilai pemulusan tripel } \\ \mathrm{Xt} & =\text { Data aktual pada waktu ke-t } \\ a_{t} & =\text { Pemulusan total } \\ b_{t} & =\text { Pemulusan Tren } \\ C_{t} & =\text { Pemulusan Kuadratik } \\ F_{t+m} & =\text { nilai ramalan } \\ m & =\text { periode masa mendatang }\end{array}$




\section{III.METODE PENELITIAN}

\section{A. Analisis Sistem}

Proses analisis sistem yang digunakan dalam merancang dan membuat sistem, didapatkan hasil wawancara terhadap Supervisor PT. PLN Rayon Lamongan bahwa disetiap akhir bulan terdapat beberapa petugas PLN Lamongan yang disebut sebagai petugas pencatat meteran (carter) PLN, rutin setiap bulan mendatangi rumah-rumah pelanggan untuk mencatat penggunaan $\mathrm{kWh}$ listrik pada meteran yang telah digunakan pelanggan setiap akhir bulan berdasarkan daerah bagiannya masing-masing.

Hasil pencatatan meteran pelanggan nantinya dikumpulkan dan dilaporkan kepada pihak PLN untuk dilakukan proses pengelolahan data selanjutnya. Ketika petugas melakukan pencatatan ditemui beberapa kendala, seperti rumah pelanggan yang kosong dan pagar terkunci. Akibatnya petugas tidak dapat melakukan pencatatan penggunaan listrik pelanggan pada bulan tersebut. Untuk mengatasi masalah itu petugas pencatat meteran mengambil hasil penggunaan rata-rata dari penggunaan listrik pelanggan beberapa bulan sebelumnya untuk penagihan bulan berikutnya. Solusi pengambilan rata-rata penggunaan listrik pelanggan dirasa kurang tepat karena jika salah dalam menentukan tagihan dapat menimbulkan kerugian bagi pihak PLN atau pelanggan PLN.

Permasalahan yang dihadapi berdasarkan analisa yaitu pengambilan rata-rata penggunaan listrik pelanggan yang tidak dapat dilakukan pencatatan oleh petugas akibat permasalahan tertentu dan pelanggan yang tidak bisa mengira-ngira berapa penggunaan $\mathrm{kWh}$ listrik yang digunakan dalam periode yang akan datang sehingga mengakibatkan kemungkinan pemborosan energi listrik yang akan berdampak pada tagihan biaya. Maka dari permasalahan tersebut dibutuhkan suatu sistem prediksi penggunaan kWh listrik pelanggan PT. PLN Rayon Lamongan periode selanjutnya yang mampu memberikan solusi untuk mengetahui prediksi penggunaan listrik pelanggan yang nantinya berguna bagi petugas pencatat meteran dan pelanggan PLN Rayon Lamongan.

\section{B. Hasil Analisis}

Hasil analisis yang menerangkan masalah petugas pencatat meteran dan pelanggan untuk mengetahui penggunaan $\mathrm{kWh}$ listrik pada periode selanjutnya hanya mengacu dari rata-rata hasil tagihan pada bulan sebelumnya tanpa memperhitungkan analisis data penggunaan $\mathrm{kWh}$ listrik beberapa bulan dan beberapa tahun sebelumnya dengan perhitungan yang nyata. Analisis seperti itu dapat menyebabkan hasil keputusan yang tidak objektif dan dapat mengalami kesalahan sehingga akan mengakibatkan kerugian kepada pihak PLN atau pelanggan PLN. Maka dari permasalahan tersebut dibutuhkan suatu sistem prediksi penggunaan $\mathrm{kWh}$ listrik pelanggan PT. PLN Rayon Lamongan yang mampu memberikan solusi untuk mengetahui prediksi penggunaan listrik pelanggan periode selanjutnya.
Aplikasi peramalan (forecasting) ini memprediksi atau meramalkan penggunaan $\mathrm{kWh}$ listrik pelanggan di PT. PLN Lamongan periode selanjutnya dimana data yang digunakan adalah data penggunaan $\mathrm{kWh}$ listrik dari pelanggan PLN di Lamongan. Sistem ini memprediksi penggunaan $\mathrm{kWh}$ listrik pelanggan di PT. PLN Lamongan berdasarkan 1 atribut yaitu nilai penggunaan $\mathrm{kWh}$ listrik pada bulan-bulan sebelumnya dari tahun 2014 sampai tahun 2016. Data penggunaan $\mathrm{kWh}$ listrik pelanggan diperoleh dari database PT. PLN rayon Lamongan.

\section{Diagram Konteks}

Dari Gambar 1, menggambarkan bahwa sistem prediksi penggunaan $\mathrm{kWh}$ listrik pelanggan PT. PLN Lamongan ini melibatkan 3 entitas yakni Admin, Petugas Carter (pencatat meteran) dan Pelanggan. Admin dapat mengelolah data identitas pelanggan kepada sistem sedangkan sistem dapat menampilkan data detail pelanggan kepada Admin. Petugas Carter (pencatat meteran) dapat memasukkan data penggunaa $\mathrm{kWh}$ listrik pelanggan PLN Lamongan per bulan dan sistem dapat menampilkan laporan hasil prediksi penggunaan $\mathrm{kWh}$ listrik pelanggan kepada Petugas Carter (pencatat meteran).

Pelanggan dapat melakukan proses perhitungan berdasarkan data penggunaan $\mathrm{kWh}$ sendiri dan melihat hasil dari perhitungan prediksi penggunaan $\mathrm{kWh}$ listrik milik sendiri.

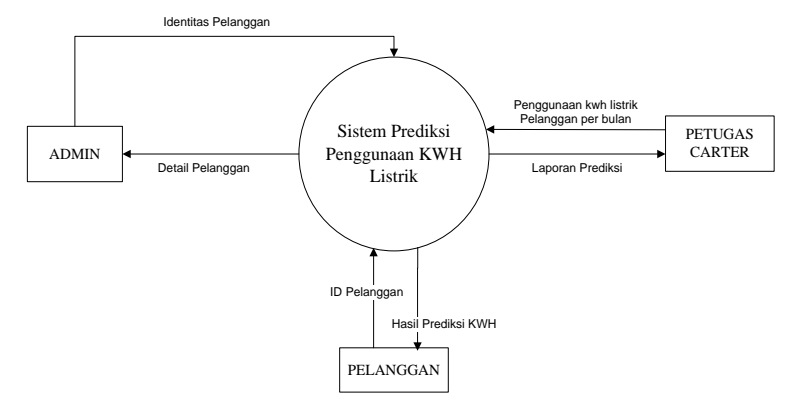

Gambar 1. Diagram Konteks Sistem Prediksi Penggunaan KWH Listrik Pelanggan

\section{Diagram Berjenjang}

Diagram berjenjang merupakan penggunaan awal dalam menggambarkan Data Flow Diagram (DFD) ke level-level lebih bawah lagi. Berikut penjelasan Gambar 2. berdasarkan kerangka diagram berjenjang diatas terlihat bahwa sistem yang dibuat terdiri dari 3 (Tiga) level yaitu :

1) Top level : Sistem Prediksi Penggunaan kWh listrik pelanggan

2) Level 0 : Merupakan hasil break down dari proses keseluruhan dari Sistem Prediksi Penggunaan $\mathrm{kWh}$ listrik pelanggan menjadi beberapa sub proses yaitu :

a) Management data

b) Perhitungan Triple Exponential Smoothing (Brown)

c) Perhitungan MAD \& MAPE

d) Laporan hasil prediksi

3) Level 1 : Merupakan sub proses dari beberapa proses pada level 0 Sistem Prediksi Penggunaan 
$\mathrm{kWh}$ listrik pelanggan yang menggambarkan beberapa proses detail yaitu :
a) Perhitungan pemulusan tunggal $\left(\mathrm{S}^{\prime} \mathrm{t}\right)$
b) Perhitungan pemulusan ganda ( $\left.\mathrm{S}^{\prime} \mathrm{t}\right)$
c) Perhitungan pemulusan Tripel ( $\mathrm{S}$ ', 't)
d) Perhitungan pemulusan total (at)
e) Perhitungan pemulusan tren (bt)
f) Perhitungan pemulusan kuadratik (ct)
g) Perhitungan prediksi $(\mathrm{Ft}+\mathrm{m})$

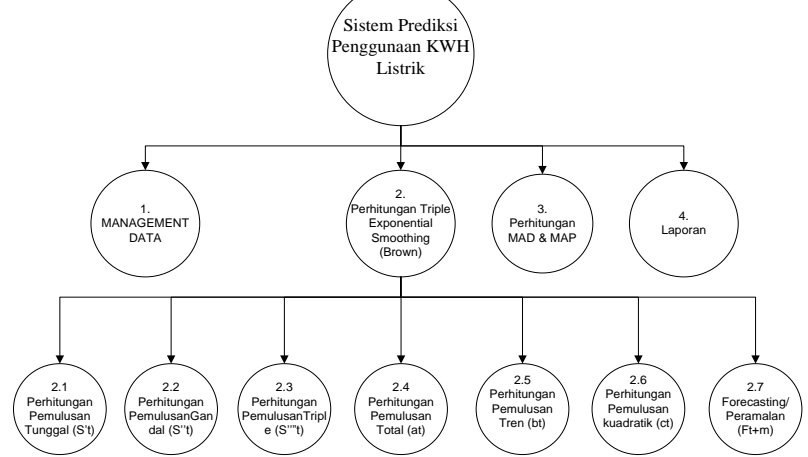

Gambar 2. Diagram Berjenjang Sistem Prediksi Penggunaan KWH Listrik Pelanggan

\section{E. Data Flow Diagram Level}

Berdasarkan Gambar 3, menjelaskan beberapa proses yang terjadi pada sistem prediksi penggunaan $\mathrm{kWh}$ pelanggan dimana proses tersebut terbagi menjadi 4 proses yaitu : Management Data, Perhitungan Triple Exponential Smoothing (Brown), Perhitungan MAD \& MAPE dan Laporan Hasil Prediksi. Setiap stake holder memiliki peranan masing-masing dalam jalannya sistem. Output dari sistem adalah prediksi penggunaan $\mathrm{kWh}$ listrik pelanggan pada periode berikutnya yang nantinya akan dibuatkan laporan dari hasil prediksi yang bisa dilihat oleh petugas Carter (Pencatat Meteran).

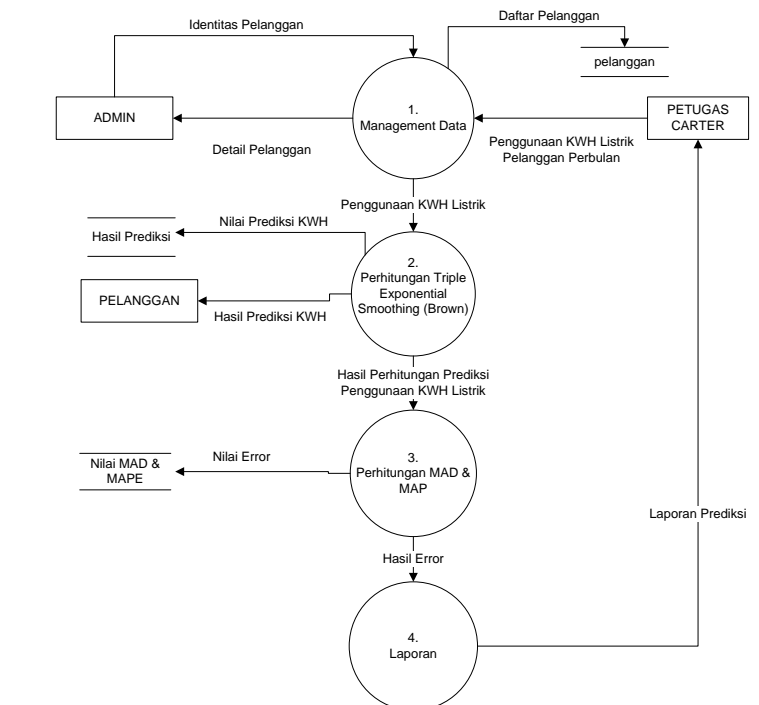

Gambar 3. DFD Level 0 Sistem Prediksi Penggunaan KWH Listrik Pelanggan
F. Data Flow Diagram Level 1

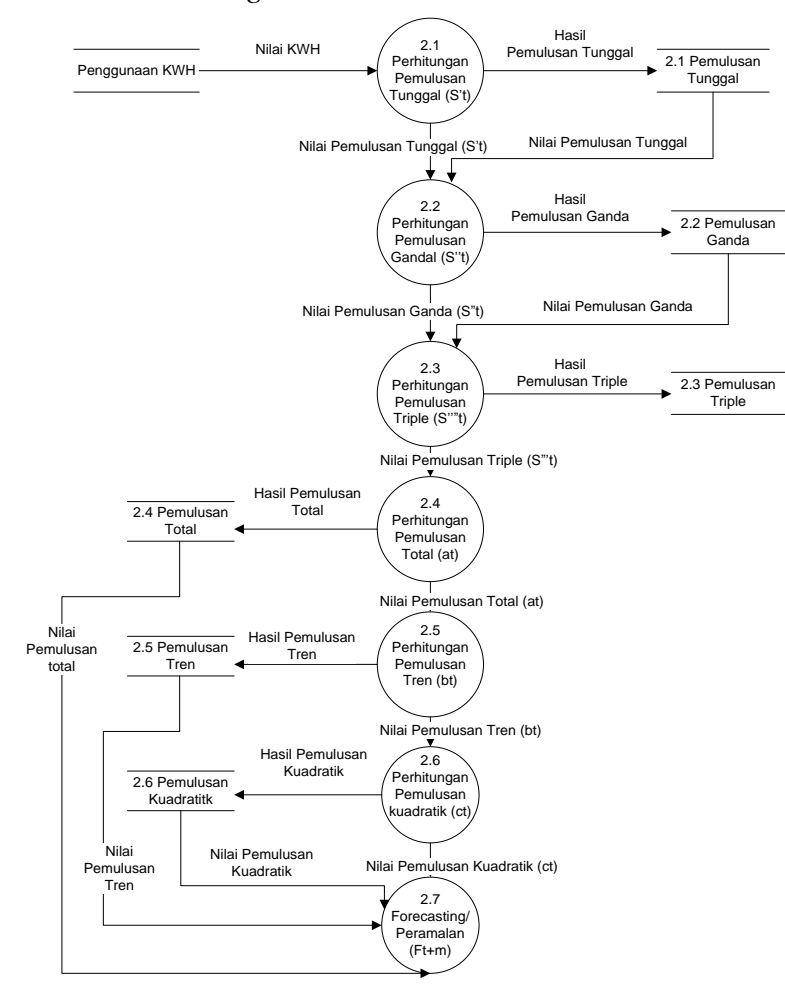

Gambar 4. DFD Level 1 Sistem Prediksi Penggunaan KWH Listrik Pelanggan

DFD level 1 proses 1 yang ditunjukan pada Gambar 4 menjelaskan beberapa proses yang terjadi pada sistem prediksi penggunaan $\mathrm{kWh}$ pelanggan yang merupakan hasil break down dari DFD level 0 untuk mendapatkan perilaku sistem yang lebih detail

\section{HASIL DAN PEMBAHASAN}

\section{A. Implementasi Sistem}

\section{A.1. Halaman Login}

Tampilan awal pada saat user (pengguna) membuka sistem adalah tampilan login. Tampilan login ini digunakan untuk membatasi pemakaian sistem prediksi agar tidak digunakan divisi - divisi yang lainnya. Dalam halaman ini user (pengguna) diharuskan mengisi Username dan Password. Gambar 5. berikut ini adalah tampilan login pada sistem prediksi yang telah dibangun. user (pengguna) dalam sistem prediksi penggunaan $\mathrm{kWh}$ listrik pelanggan ini terbagi menjadi 3 yaitu Admin, Petugas dan Pelanggan PLN.

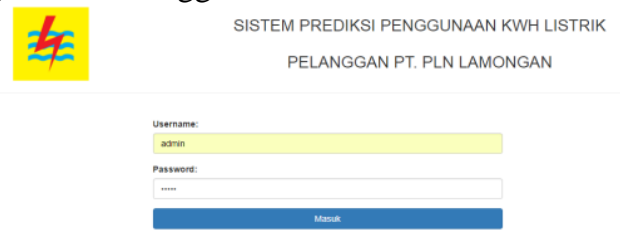

Gambar 5. Halaman Login Sistem Prediksi Penggunaan KWH Listrik Pelanggan 


\section{A.2. Halaman Home}

Setelah user (pengguna) berhasil melakukan login ke sistem, maka akan muncul tampilan awal seperti Gambar 6.



Gambar 6. Halaman Home Sistem Prediksi Penggunaan KWH Listrik Pelanggan

\section{A.3. Halaman Data Admin}

Gambar 7 adalah halaman user (pengguna) yang digunakan untuk membatasi pengguna dalam pemakaian sistem. Dalam halaman tersebut Admin sistem mempunyai hak akses yaitu menambah, merubah dan menghapus data user (pengguna) dari sistem prediksi penggunaan $\mathrm{kWh}$ listrik pelanggan.

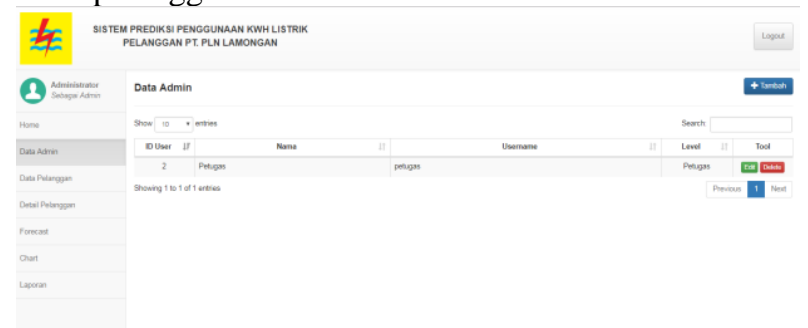

Gambar 7. Halaman Data Admin Sistem Prediksi Penggunaan KWH Listrik Pelanggan

\section{A.4. Halaman Data Pelanggan}

Halaman data pelanggan merupakan halaman yang menampilkan data dari pelanggan PT. PLN Lamongan. Admin mempunyai hak akses dalam menambah, merubah dan menghapus data pelanggan pada sistem prediksi penggunaan kWh listrik pelanggan. Lihat pada Gambar 8.

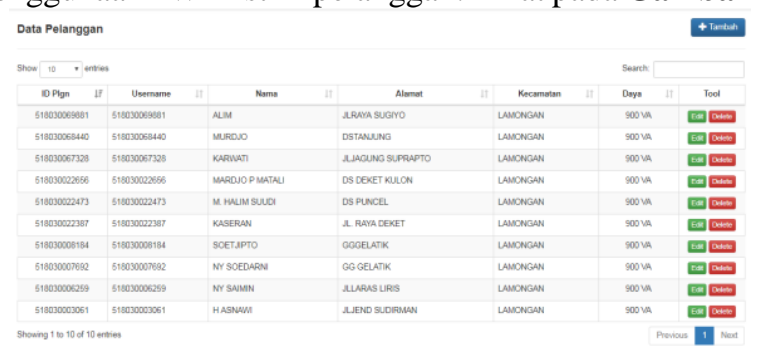

Gambar 8. Halaman Data Pelanggan Sistem Prediksi Penggunaan KWH Listrik Pelanggan

\section{A.5. Halaman Detail Pelanggan}

Halaman detail pelanggan menampilkan penggunaan kWh listrik pelanggan PT. PLN Lamongan per periode (bulan). Admin dan Petugas mempunyai hak akses dalam menambah, merubah dan menghapus data penggunaan kWh listrik pelanggan pada sistem lihat pada Gambar 9.

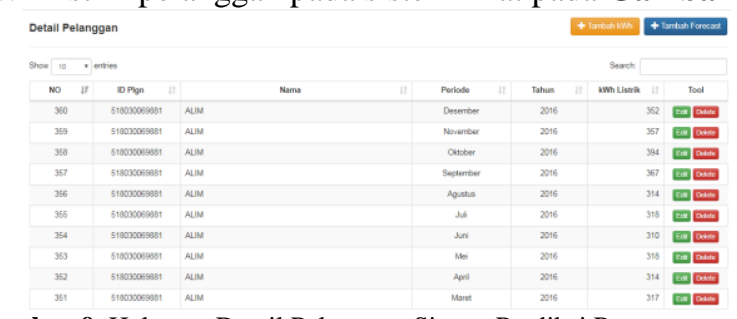

Gambar 9. Halaman Detail Pelanggan Sistem Prediksi Penggunaan KWH Listrik Pelanggan

\section{A.6. Halaman Forecast}

Halaman ini digunakan untuk memprediksi penggunaan $\mathrm{kWh}$ listrik pelanggan pada bulan selanjutnya. Pada tahap pengujian sistem akan dilakukan penginputan data awal sebagai data aktual dari 10 pelanggan berbeda. Data aktual tersebut bertujuan sebagai acuan untuk memprediksi penggunaan kWh listrik di bulan selanjutnya. Data yang telah terinputkan dapat dilihat seperti Gambar 10. Setelah menginputkan data aktual per periode penggunaan $\mathrm{kWh}$ listrik per 10 pelanggan kemudian kita dapat melakukan proses penghitungan prediksi dengan Triple Exponential Smoothing (brown). Proses forecasting dapat dilakukan dengan perhitungan otomatis pertahun dan hanya perperiode (perbulan).

\section{a) Perhitungan Forecast per Tahun}

Proses perhitungan berjalan saat setelah kita memilih nama pelanggan, memilih acuan perhitungan peramalan yaitu acuan 3 bulan, 6 bulan 12 bulan dan data keseluruhan, memilih tahun peramalan, menentukan nilai alpha dan kemudian menekan tombol proses untuk proses forecasting. Secara otomatis data - data yang tersimpan pada database yang sebelumnya kita inputkan akan diproses dengan Triple exponential smoothing (Brown), Mean Absolute deviation mean (MAD) dan Mean absolute percentage error (MAPE) pada sistem.

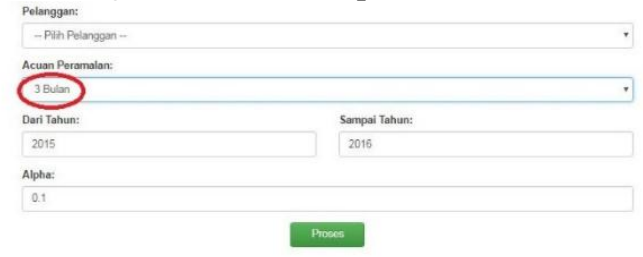

Gambar 10. Form Forecast Sistem Prediksi Penggunaan KWH Listrik Pelanggan Pertahun Acuan 3 Bulan

Selain menggunakan acuan 3 bulan sistem juga dapat menghitung menggunakan acuan 6 bulan. Lihat pada Gambar 11.

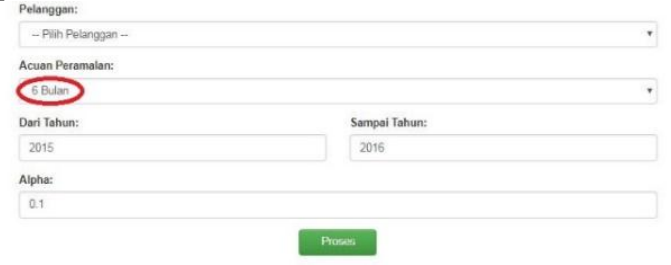

Gambar 11. Form Forecast Sistem Prediksi Penggunaan KWH Listrik Pelanggan Pertahun Acuan 6 Bulan 
Selain menggunakan acuan 3 bulan dan 6 bulan system juga dapat menghitung menggunakan acuan 12 bulan. Lihat pada Gambar 12.

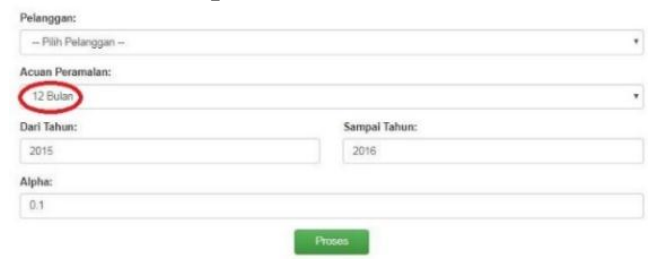

Gambar 12. Form Forecast Sistem Prediksi Penggunaan KWH Listrik Pelanggan Pertahun Acuan 12 Bulan

\section{A.7. Halaman Chart}

Halaman ini digunakan untuk menampilkan chart untuk membandingkan hasil perhitungan MAPE dalam mengukur kesalahan dari semua hasil prediksi per pelanggan otomatis berdasarkan nilai alpha $0,1-0,9$. Berikut merupakan contoh pengujian halaman chart dengan menggunakan pelanggan atas nama Ny Soedarni. Perhitungan dilakukan selama 2 tahun yaitu Januari 2015 - Desember 2016.

Hasil perhitungan Ny Soedarni menggunakan acuan 3 bulan dengan alpha 0,1- 0,9 lihat pada Gambar 13.

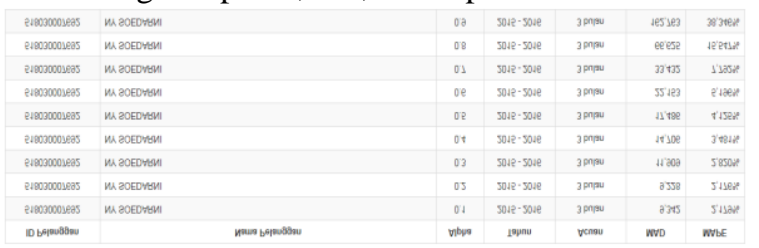

Gambar 13. Hasil Perhitungan MAD Dan MAPE Pelanggan Ny Soedarni Menggunakan Acuan 3 Bulan Alpha 0,1 - 0,9

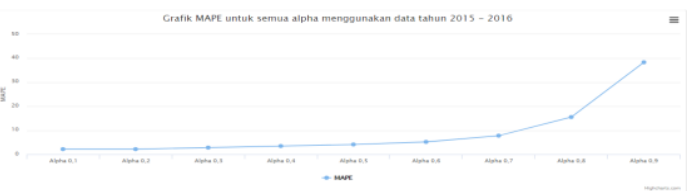

Gambar 14. Grafik MAD Dan MAPE Pelanggan Ny Soedarni Menggunakan Acuan 3 Bulan Alpha 0,1 - 0,9

Hasil perhitungan Ny Soedarni menggunakan acuan 6 bulan dengan alpha 0,1- 0,9 lihat pada Gambar 15.

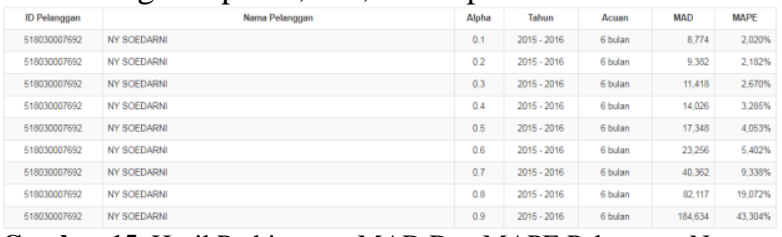

Gambar 15. Hasil Perhitungan MAD Dan MAPE Pelanggan Ny Soedarni Menggunakan Acuan 6 Bulan Alpha 0,1 - 0,9

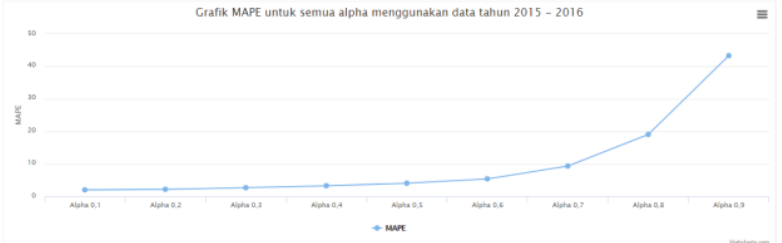

Gambar 16. Grafik MAD Dan MAPE Pelanggan Ny Soedarni Menggunakan Acuan 6 Bulan Alpha 0,1 - 0,9
Hasil perhitungan Ny Soedarni menggunakan acuan 12 bulan dengan alpha 0,1- 0,9 lihat pada Gambar 17 sebagai berikut :

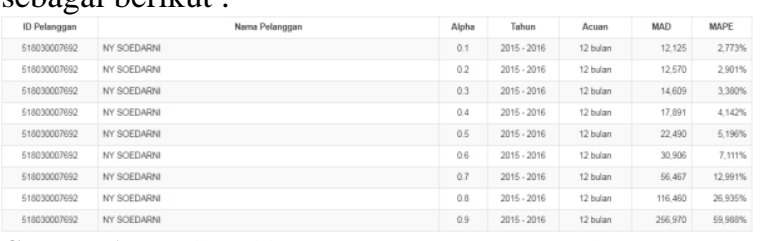

Gambar 17. Hasil Perhitungan MAD Dan MAPE Pelanggan Ny Soedarni Menggunakan Acuan 12 Bulan Alpha 0,1 - 0,9



Gambar 18 Grafik MAD Dan MAPE Pelanggan Ny Soedarni Menggunakan Acuan 6 Bulan Alpha 0,1 - 0,9

\section{A.8. Halaman Laporan}

Halaman ini digunakan untuk menampilkan laporan dari hasil prediksi pada sistem penggunaan $\mathrm{kWh}$ listrik pelanggan periode selanjutnya. Hasil laporan bisa diakses oleh petugas dan dapat dicetak yang nantinya dapat digunakan sebagai bukti dasar pencatatan penggunaan kWh listrik pelanggan yang kosong. Hasil laporan oleh pelanggan atas nama Alim pada periode Januari 2017 menggunakan acuan data 6 bulan sebelumnya dengan nilai alpha 0,1 dengan hasil forecast kWh 358,771. Hasil laporan dapat dilihat pada Gambar 19.

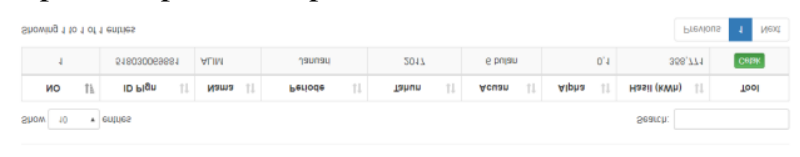

Gambar 19. Halaman Laporan Sistem Prediksi Penggunaan KWH Listrik Pelanggan

\section{B. Pengujian Sistem}

Untuk Analisa hasil pengujian sistem penulis menggunakan data penggunaan $\mathrm{kWh}$ listrik 10 pelanggan PLN Lamongan dengan contoh salah satu pengujian sistem terhadap pelanggan yaitu pelanggan atas nama $\mathrm{Ny}$ Soedarni. Pada pengujian ini dilakukan 3 tahapan pengujian yaitu menggunakan acuan data 3 bulan, 6 bulan dan 12 bulan sebelumnya untuk menentukan peramalan bulan selanjutnya mulai bulan April 2015 - Desember 2016 selama 2 tahun dengan besaran nilai alpha mulai 0.1 sampai 0.9 untuk mengetahui hasil forecast manakah yang terbaik dengan memperoleh nilai kesalahan peramalan Mean Absolut Deviation (MAD) terkecil dan Mean Absolut Percentage Error (MAPE).

\section{B.1. Pengujian Ny Soedarni}

\section{a) B.1.1. Pengijian Acuan 3 Bulan}

TABLE XV. Hasil AKhIR PEnguJian PelangGan Ny SoEdarn DENGan Data ACUan 3 Bulan AlPha $0.1-0.9$ 


\begin{tabular}{|c|c|c|c|c|c|c|}
\hline NO & Nama Plgn & Alpha & Tahun & Acuan & MAD & MAPE \\
\hline 1 & Ny Soedarni & 0.1 & $2015-2016$ & 3 bulan & 9,342 & $2,179 \%$ \\
\hline 2 & Ny Soedarni & 0.2 & $2015-2016$ & 3 bulan & 9,228 & $2,176 \%$ \\
\hline 3 & Ny Soedarni & 0.3 & $2015-2016$ & 3 bulan & 11,909 & $2,820 \%$ \\
\hline 4 & Ny Soedarni & 0.4 & $2015-2016$ & 3 bulan & 14,706 & $3,481 \%$ \\
\hline 5 & Ny Soedarni & 0.5 & $2015-2016$ & 3 bulan & 17,486 & $4,125 \%$ \\
\hline 6 & Ny Soedarni & 0.6 & $2015-2016$ & 3 bulan & 22,153 & $5,196 \%$ \\
\hline 7 & Ny Soedarni & 0.7 & $2015-2016$ & 3 bulan & 33,432 & $7,792 \%$ \\
\hline 8 & Ny Soedarni & 0.8 & $2015-2016$ & 3 bulan & 66,625 & $15,547 \%$ \\
\hline 9 & Ny Soedarni & 0.9 & $2015-2016$ & 3 bulan & 162,763 & $38,346 \%$ \\
\hline
\end{tabular}

Dari tabel diatas didapatkan hasil forecast yang mendekati dan memperoleh nilai kesalahan peramalan Mean Absolut Deviation (MAD) dan Mean Absolut Percentage Error (MAPE) terkecil di besaran nilai alpha 0,2 seperti di tabel I yang bergaris kuning. Dari tabel diatas dapat dilihat nilai hasil pengujian prediksi dan kesalahan peramalan MAD \& MAPE yang terpilih sebagai berikut:

TABLE XVI. Hasil Pengujian PREDiksi PelangGan Ny SOEDARNi DENGAN ACUAN 3 Bulan DENGAN AlPha $(0,2)$

\begin{tabular}{|c|c|c|c|c|c|c|}
\hline Periode & Thn & $\begin{array}{c}\text { Data } \\
\text { Pemakaian } \\
\text { (Xt) }\end{array}$ & $\mathrm{Ft}+\mathrm{m}$ & error & |error| & $\begin{array}{c}\text { |error|/ } \\
\mathrm{Xt}\end{array}$ \\
\hline Januari & 2015 & 380 & & & & \\
\hline Februari & 2015 & 395 & & & & \\
\hline Maret & 2015 & 403 & & & & \\
\hline April & 2015 & 394 & 399.111 & -5.111 & 5.111 & 0.013 \\
\hline Mei & 2015 & 403 & 397.271 & 5.729 & 5.729 & 0.014 \\
\hline Juni & 2015 & 390 & 399.775 & -9.775 & 9.775 & 0.025 \\
\hline Juli & 2015 & 403 & 394.842 & 8.158 & 8.158 & 0.020 \\
\hline Agustus & 2015 & 403 & 398.342 & 4.658 & 4.658 & 0.012 \\
\hline September & 2015 & 399 & 402.418 & \begin{tabular}{|c|}
-3.418 \\
\end{tabular} & 3.418 & 0.009 \\
\hline Oktober & 2015 & 394 & 400.617 & -6.617 & 6.617 & 0.017 \\
\hline Nopember & 2015 & 399 & 396.206 & 2.794 & 2.794 & 0.007 \\
\hline Desember & 2015 & 403 & 397.208 & 5.792 & 5.792 & 0.014 \\
\hline Januari & 2016 & 398 & 401.160 & -3.160 & 3.160 & 0.008 \\
\hline Februari & 2016 & 395 & 399.838 & -4.838 & 4.838 & 0.012 \\
\hline Maret & 2016 & 403 & 396.443 & 6.557 & 6.557 & 0.016 \\
\hline April & 2016 & 398 & 399.905 & -1.905 & 1.905 & 0.005 \\
\hline Mei & 2016 & 403 & 399.656 & 3.344 & 3.344 & 0.008 \\
\hline Juni & 2016 & 395 & 401.208 & -6.208 & 6.208 & 0.016 \\
\hline Juli & 2016 & 403 & 398.004 & 4.996 & 4.996 & 0.012 \\
\hline Agustus & 2016 & 398 & 400.133 & -2.133 & 2.133 & 0.005 \\
\hline September & 2016 & 466 & 399.656 & 66.344 & 66.344 & 0.142 \\
\hline Oktober & 2016 & 444 & 438.875 & 5.125 & 5.125 & 0.012 \\
\hline Nopember & 2016 & 415 & 449.959 & -34.959 & 34.959 & 0.084 \\
\hline
\end{tabular}

\begin{tabular}{|l|l|l|l|l|r|r|}
\hline Desember & 2016 & 430 & 427.834 & 2.166 & 2.166 & 0.005 \\
\hline \multicolumn{3}{|c|}{ TOTAL |error| } & 193.785 \\
\hline \multicolumn{3}{|c|}{ TOTAL |error|/Xt } & 0.457 \\
\hline \multicolumn{3}{|c|}{ MAD } & 9.228 \\
\hline MAPE & $2.176 \%$ \\
\hline
\end{tabular}

\section{b) B.1.2. Pengijian Acuan 6 Bulan}

TABLE XVII. Hasil AKHIR PENGUJIAN PELANGGan Ny SOEDARni Dengan Data ACuan 6 Bulan AlPha $0.1-0.9$

\begin{tabular}{|c|c|c|c|c|c|c|}
\hline NO & Nama Plgn & Alpha & Tahun & Acuan & MAD & MAPE \\
\hline 1 & Ny Soedarni & 0.1 & $2015-2016$ & 6 bulan & 8,774 & $2,020 \%$ \\
\hline 2 & Ny Soedarni & 0.2 & $2015-2016$ & 6 bulan & 9,382 & $2,182 \%$ \\
\hline 3 & Ny Soedarni & 0.3 & $2015-2016$ & 6 bulan & 11,418 & $2,670 \%$ \\
\hline 4 & Ny Soedarni & 0.4 & $2015-2016$ & 6 bulan & 14,026 & $3,285 \%$ \\
\hline 5 & Ny Soedarni & 0.5 & $2015-2016$ & 6 bulan & 17,348 & $4,053 \%$ \\
\hline 6 & Ny Soedarni & 0.6 & $2015-2016$ & 6 bulan & 23,256 & $5,402 \%$ \\
\hline 7 & Ny Soedarni & 0.7 & $2015-2016$ & 6 bulan & 40,362 & $9,338 \%$ \\
\hline 8 & Ny Soedarni & 0.8 & $2015-2016$ & 6 bulan & 82,117 & $19,072 \%$ \\
\hline 9 & Ny Soedarni & 0.9 & $2015-2016$ & 6 bulan & 184,634 & $43,304 \%$ \\
\hline
\end{tabular}

Dari tabel diatas didapatkan hasil forecast yang mendekati dan memperoleh nilai kesalahan peramalan Mean Absolut Deviation (MAD) dan Mean Absolut Percentage Error (MAPE) terkecil di besaran nilai alpha 0,1 seperti di tabel III yang bergaris kuning. Dari tabel diatas dapat dilihat nilai hasil pengujian prediksi dan kesalahan peramalan MAD \& MAPE yang terpilih sebagai berikut:

TABLE XVIII. Hasil PENGUJian PREDIKsi PelangGan Ny Soedarni Dengan Acuan 6 Bulan Dengan Nilai Alpha $(0,1)$

\begin{tabular}{|l|c|c|c|c|c|c|}
\hline \multicolumn{1}{|c|}{ Periode } & Thn & $\begin{array}{c}\text { Demakaian } \\
(\mathrm{Xt})\end{array}$ & $\mathrm{Ft}+\mathrm{m}$ & error & |error| & $\begin{array}{c}\mid \text { error|/ } \\
\mathrm{Xt}\end{array}$ \\
\hline Januari & 2015 & 380 & & & & \\
\hline Februari & 2015 & 395 & & & & \\
\hline Maret & 2015 & 403 & & & & \\
\hline April & 2015 & 394 & & & & \\
\hline Mei & 2015 & 403 & & & & \\
\hline Juni & 2015 & 390 & & & & \\
\hline Juli & 2015 & 403 & 396.289 & 6.711 & 6.711 & 0.017 \\
\hline Agustus & 2015 & 403 & 398.481 & 4.519 & 4.519 & 0.011 \\
\hline September & 2015 & 399 & 399.506 & -0.506 & 0.506 & 0.001 \\
\hline Oktober & 2015 & 394 & 399.796 & -5.796 & 5.796 & 0.015 \\
\hline Nopember & 2015 & 399 & 397.862 & 1.138 & 1.138 & 0.003 \\
\hline Desember & 2015 & 403 & 398.775 & 4.225 & 4.225 & 0.010 \\
\hline Januari & 2016 & 398 & 399.740 & -1.740 & 1.740 & 0.004 \\
\hline
\end{tabular}


INDEXIA, Vol. 1, No. 1, Februari 2019

\begin{tabular}{|l|c|c|r|r|r|r|}
\hline Februari & 2016 & 395 & 398.952 & -3.952 & 3.952 & 0.010 \\
\hline Maret & 2016 & 403 & 397.751 & 5.249 & 5.249 & 0.013 \\
\hline April & 2016 & 398 & 399.600 & -1.600 & 1.600 & 0.004 \\
\hline Mei & 2016 & 403 & 399.208 & 3.792 & 3.792 & 0.009 \\
\hline Juni & 2016 & 395 & 400.044 & -5.044 & 5.044 & 0.013 \\
\hline Juli & 2016 & 403 & 398.699 & 4.301 & 4.301 & 0.011 \\
\hline Agustus & 2016 & 398 & 400.273 & -2.273 & 2.273 & 0.006 \\
\hline September & 2016 & 466 & 399.414 & 66.586 & 66.586 & 0.143 \\
\hline Oktober & 2016 & 444 & 419.443 & 24.557 & 24.55704 & 0.055 \\
\hline Nopember & 2016 & 415 & 428.519 & -13.519 & 13.519 & 0.033 \\
\hline Desember & 2016 & 430 & 427.569 & 2.431 & 2.431 & 0.006 \\
\hline & \multicolumn{7}{|c|}{ TOTAL |error| } & 157.939 \\
\hline
\end{tabular}

c) B.1.3. Pengijian Acuan 12 Bulan

TABLE XIX. HASIL AKHIR PENGUJIAN PELANGgan Ny SOEDARNI Dengan Data Acuan 12 Bulan AlPha $0.1-0.9$

\begin{tabular}{|c|c|c|c|c|c|c|}
\hline NO & Nama Plgn & Alpha & Tahun & Acuan & MAD & MAPE \\
\hline 1 & Ny Soedarni & 0.1 & $2015-2016$ & 12 bulan & 12,125 & $2,773 \%$ \\
\hline 2 & Ny Soedarni & 0.2 & $2015-2016$ & 12 bulan & 12,570 & $2,901 \%$ \\
\hline 3 & Ny Soedarni & 0.3 & $2015-2016$ & 12 bulan & 14,609 & $3,380 \%$ \\
\hline 4 & Ny Soedarni & 0.4 & $2015-2016$ & 12 bulan & 17,891 & $4,142 \%$ \\
\hline 5 & Ny Soedarni & 0.5 & $2015-2016$ & 12 bulan & 22,490 & $5,196 \%$ \\
\hline 6 & Ny Soedarni & 0.6 & $2015-2016$ & 12 bulan & 30,906 & $7,111 \%$ \\
\hline 7 & Ny Soedarni & 0.7 & $2015-2016$ & 12 bulan & 56,467 & $12,991 \%$ \\
\hline 8 & Ny Soedarni & 0.8 & $2015-2016$ & 12 bulan & 116,460 & $26,935 \%$ \\
\hline 9 & Ny Soedarni & 0.9 & $2015-2016$ & 12 bulan & 256,970 & $59,988 \%$ \\
\hline
\end{tabular}

Dari tabel diatas didapatkan hasil forecast yang mendekati dan memperoleh nilai kesalahan peramalan Mean Absolut Deviation (MAD) dan Mean Absolut Percentage Error (MAPE) terkecil di besaran nilai alpha 0,1 seperti di tabel V yang bergaris kuning. Dari tabel diatas dapat dilihat nilai hasil pengujian prediksi dan kesalahan peramalan MAD \& MAPE yang terpilih sebagai berikut:

TABLE XX. Hasil Pengujian Prediksi Pelanggan Ny SoEdarni Dengan ACuan 12 Bulan Dengan Nilai Alpha $(0,1)$

\begin{tabular}{|l|c|c|l|l|l|l|}
\hline Periode & Thn & $\begin{array}{c}\text { Data } \\
\text { Pemakaian } \\
(\mathrm{Xt})\end{array}$ & $\mathrm{Ft}+\mathrm{m}$ & Error & |error| & $\begin{array}{c}\text { |error|/ } \\
\mathrm{Xt}\end{array}$ \\
\hline Januari & 2015 & 380 & & & & \\
\hline Februari & 2015 & 395 & & & & \\
\hline Maret & 2015 & 403 & & & & \\
\hline April & 2015 & 394 & & & & \\
\hline Mei & 2015 & 403 & & & & \\
\hline Juni & 2015 & 390 & & & & \\
\hline Juli & 2015 & 403 & & & & \\
\hline Agustus & 2015 & 403 & & & & \\
\hline September & 2015 & 399 & & & & \\
\hline
\end{tabular}

\begin{tabular}{|l|c|c|c|r|r|r|}
\hline Oktober & 2015 & 394 & & & & \\
\hline Nopember & 2015 & 399 & & & & \\
\hline Desember & 2015 & 403 & & & & \\
\hline Januari & 2016 & 398 & 404.100 & -6.100 & 6.100 & 0.015 \\
\hline Februari & 2016 & 395 & 400.134 & -5.134 & 5.134 & 0.013 \\
\hline Maret & 2016 & 403 & 396.989 & 6.011 & 6.011 & 0.015 \\
\hline April & 2016 & 398 & 400.580 & -2.580 & 2.580 & 0.006 \\
\hline Mei & 2016 & 403 & 398.052 & 4.948 & 4.948 & 0.012 \\
\hline Juni & 2016 & 395 & 402.387 & -7.387 & 7.387 & 0.019 \\
\hline Juli & 2016 & 403 & 397.801 & 5.199 & 5.199 & 0.013 \\
\hline Agustus & 2016 & 398 & 399.033 & -1.033 & 1.033 & 0.003 \\
\hline September & 2016 & 466 & 399.505 & 66.495 & 66.495 & 0.143 \\
\hline Oktober & 2016 & 444 & 420.677 & 23.323 & 23.323 & 0.053 \\
\hline Nopember & 2016 & 415 & 428.841 & -13.841 & 13.841 & 0.033 \\
\hline Desember & 2016 & 430 & 426.548 & 3.452 & 3.452 & 0.008 \\
\hline & & & & & & \\
\hline
\end{tabular}

\section{Keberhasilan}

Pengujian dilakukan pada 10 pelanggan PLN Lamongan dengan menggunakan nilai antara 0.1 sampai 0.9 untuk mendapatkan hasil peramalan dengan nilai kesalahan peramalan Mean Absolut Deviation (MAD) dan Mean Absolut Percentage Error (MAPE) terkecil menggunakan acuan data 3 bulan, 6 bulan dan 12 bulan sebelumnya dalam kurun waktu 2 tahun yaitu Januari 2015 - 2016.

\section{C.1. Perbandingan Peramalan 10 Pelanggan}

Perbandingan hasil kesalahan peramalan terbaik dari 10 pelanggan berdasarkan acuan data 3 bulan, 6 bulan dan 12 bulan sebelumnya dapat dilihat pada tabel VII berikut:

TABLE XXI. Perbandingan Hasil Kesalahan Peramalan TERBAIK DARI 10 PELANGGAN PLN LAMONGAN

\begin{tabular}{|c|c|c|c|c|c|c|c|c|c|}
\hline \multirow[b]{2}{*}{ Nama } & \multicolumn{3}{|c|}{3 Bulan } & \multicolumn{3}{|c|}{6 Bulan } & \multicolumn{3}{|c|}{12 Bulan } \\
\hline & $\begin{array}{l}\text { alp } \\
\text { ha }\end{array}$ & MAD & MAPE & $\begin{array}{c}\text { Alph } \\
\text { a }\end{array}$ & MAD & MAPE & $\begin{array}{c}\text { Alph } \\
\text { a }\end{array}$ & MAD & MAPE \\
\hline Ny Soedarni & 0,2 & 9,228 & $2,176 \%$ & 0,1 & 8,774 & $2,020 \%$ & 0,1 & 12,125 & $2,773 \%$ \\
\hline Murdjo & 0,1 & 7,612 & $2,672 \%$ & 0,1 & 7,774 & $2,721 \%$ & 0,1 & 10,942 & $3,827 \%$ \\
\hline Kaseran & 0,1 & 6,228 & $2,696 \%$ & 0,1 & 5,923 & $2,553 \%$ & 0,1 & 8,310 & $3,581 \%$ \\
\hline M. Halim S. & 0,2 & 6,277 & $2,348 \%$ & 0,2 & 6,164 & $2,285 \%$ & 0,2 & 8,212 & $3,004 \%$ \\
\hline Mardjo P M & 0,2 & 9,590 & $5,020 \%$ & 0,3 & 10,811 & $5,646 \%$ & 0,3 & 14,488 & $7,687 \%$ \\
\hline H. Asnawi & 0,2 & 12,663 & $2,544 \%$ & 0,2 & 14,080 & $2,769 \%$ & 0,2 & 18,714 & $3,620 \%$ \\
\hline NY Saimin & 0,3 & 19,221 & $4,277 \%$ & 0,2 & 26,762 & $5,799 \%$ & 0,2 & 35,767 & $7,760 \%$ \\
\hline Soetjipto & 0,2 & 4,849 & $2,065 \%$ & 0,1 & 4,521 & $1,886 \%$ & 0,1 & 5,939 & $2,452 \%$ \\
\hline Karwati & 0,2 & 8,936 & $2,646 \%$ & 0,1 & 9,301 & $2,673 \%$ & 0,1 & 12,637 & $3,587 \%$ \\
\hline Alim & 0,1 & 9,821 & $2,777 \%$ & 0,1 & 9,267 & $2,566 \%$ & 0,1 & 12,651 & $3,463 \%$ \\
\hline Rata-rat & $\frac{0,1}{\mathrm{MAPE}}$ & Bulan & & & & $3,092 \%$ & 2,1 & ulan & $4,175 \%$ \\
\hline
\end{tabular}

Berdasarkan Tabel VII didapatkan kesimpulan Perbandingan Hasil Kesalahan Peramalan Terbaik Dari pelanggan Ny Soedarni menggunakan acuan 6 bulan sebelumnya dengan nilai alpha 0,1 menghasilkan nilai MAD 8,774 dan MAPE 2,020\%, pelanggan Murdjo 
menggunakan acuan 3 bulan sebelumnya dengan nilai alpha 0,1 menghasilkan nilai MAD 7,612 dan MAPE $2,672 \%$, pelanggan Kaseran menggunakan acuan 6 bulan sebelumnya dengan nilai alpha 0,1 menghasilkan nilai MAD 5,923 dan MAPE 2,553\%, pelanggan M. Halim Suudi menggunakan acuan 6 bulan sebelumnya dengan nilai alpha 0,2 menghasilkan nilai MAD 6,164 dan MAPE 2,285\%, pelanggan Mardjo P Matali menggunakan acuan 3 bulan sebelumnya dengan nilai alpha 0,2 menghasilkan nilai MAD 9,590 dan MAPE 5,020\%, pelanggan $H$. Asnawi menggunakan acuan 3 bulan sebelumnya dengan nilai alpha 0,2 menghasilkan nilai MAD 12,663 dan MAPE 2,544\%, pelanggan NY Saimin menggunakan acuan 3 bulan sebelumnya dengan nilai alpha 0,3 menghasilkan nilai MAD 19,221 dan MAPE 4,277\%, pelanggan Soetjipto menggunakan acuan 6 bulan sebelumnya dengan nilai alpha 0,1 menghasilkan nilai MAD 4,521 dan MAPE $1,886 \%$, pelanggan Karwati menggunakan acuan 3 bulan sebelumnya dengan nilai alpha 0,2 menghasilkan nilai MAD 8,936 dan MAPE 2,646\% dan pelanggan Alim menggunakan acuan 6 bulan sebelumnya dengan nilai alpha 0,1 menghasilkan nilai MAD 9,267 dan MAPE 2,566\%.

Hasil dari pengujian pada 10 pelanggan PLN Lamongan berdasarkan acuan 3 bulan, 6 bulan dan 12 bulan menghasilkan error rata-rata nilai MAPE terkecil yaitu pada pengujian menggunakan acuan 3 bulan pada Tabel VII dengan block warna merah menghasilkan nilai rata-rata $2,922 \%$ dan nilai alpha yang paling banyak digunakan pada pengujian 3 bulan tersebut yaitu alpha 0,2

\section{PENUTUP}

\section{A. Kesimpulan}

Berdasarkan hasil penelitihan yang telah dilakukan, kesimpulan yang dapat diambil dari penelitian ini adalah sebagai berikut :

1. Metode peramalan Triple exponential smoothing (Brown) ini dapat diimplementasikan untuk studi kasus prediksi penggunaan $\mathrm{kWh}$ listrik bulan selanjutnya di PT. PLN (persero) Lamongan.

2. Berdasarkan pada analisis hasil pengujian sistem, dapat disimpulkan bahwa aplikasi ini dapat melakukan perhitungan peramalan dengan cukup baik.

3. Sistem ini memiliki beberapa variasi perhitungan, mulai dari perhitungan dengan data acuan 3 bulan, 6 bulan, 12 bulan dan data keseluruhan dengan menggunakan 9 alpha yang berbeda yaitu $0,1-0,9$.

4. Dari pengujian pada 10 pelanggan PLN Lamongan berdasarkan acuan 3 bulan, 6 bulan dan 12 bulan menghasilkan error rata-rata nilai MAPE terkecil yaitu pengujian menggunakan acuan 3 bulan dengan nilai rata-rata 2,922\% dan nilai alpha yang paling banyak digunakan yaitu alpha 0,2 .

\section{B. Saran}

Beberapa saran yang perlu penulis sampaikan untuk pengembangan sistem selanjutnya adalah :

1. Metode ini memiliki kesulitan untuk menentukan tingkat prediksi terbaik dengan nilai error terkecil karena diharuskan untuk memprediksi dengan 9 alpha berbeda untuk mengetahui alpha terbaik dengan memiliki tingkat nilai selisih error terkecil.

2. Diharapkan adanya penelitian dengan metode selain trend linier seperti menggunakan Pemodelan Regresi Linier dengan metode Algoritma Genetika untuk kemudian dibandingkan dengan metode Triple Exponential Smoothing (Brown) ini

\section{DAFTAR PUSTAKA}

[43] Hontong, Febry. dkk. Prediksi Kebutuhan Energi Listrik Sulawesi Utara Menggunakan Artificial Neural Network dan Metode Triple Exponential Smoothing. Vol. 5, No. 2.

[44] Makridakis, Spyros. dkk. 1999. Metode dan Aplikasi Peramalan. Jilid 1. Diterjemahkan oleh: Untung Sus Ardianto dan Abdul Basith. Jakarta: Erlangga.

[45] Peraturan Mentri (Permen) Tarif Tenaga Listrik ESDM No. 28 Tahun 2016. www.pln.co.id.

[46] Permatasari, Arini Indah dan Wayan Firdaus mahmudy. 2015. Pemodelan Regresi Linier Dalam Konsumsi KWH Listrik di Kota Batu Menggunakan Algoritma Genetika. Program Studi Informatika/Ilmu Komputer Program Teknologi Informasi dan Ilmu Komputer Universitas Brawijaya. Vol. 5, no. 14.

[47] S. Ruliah dan Rendi Rolyadely. 2014. Prediksi Pemakaian Listrik Dengan Pendekatan Back Propogation. Sekolah Tinggi Manajaemen Informatika dan Komputer Banjarbaru. Vol. 3, No. 1.

[48] Saleh, Alfa. 2015. Implementasi Metode Klasifikasi Nä̈ve Bayes Dalam Memprediksi Besarnya Penggunaan Listrik Rumah Tangga. Universitas Potensi Utama. Vol. 2, No.3.

[49] Wirautama, Bagus Fajar. 2017. Prediksi Produksi Air Studi Kasus Pdam Kabupaten Gresik Dengan Metode Triple Exponential Smoothing (Brown). Tugas Akhir. Fakultas Teknik Universitas Muhammadiyah Gresik. 